\title{
Living-working and the axiomatic of capitalism: a study based on media outlets in the architecture, decoration, and design segments
}

\author{
AnA Carolina dos SANTOS BORTOLINI ${ }^{1}$ \\ CARMEM LIGIA IOCHINS GRISCI ${ }^{1}$ \\ ANA ELÍSIA DA COSTA ${ }^{2}$
}

\author{
${ }^{1}$ Universidade Federal do Rio Grande do Sul (UFRGS) / Escola de AdMinistração, Porto Alegre - RS, BraziL

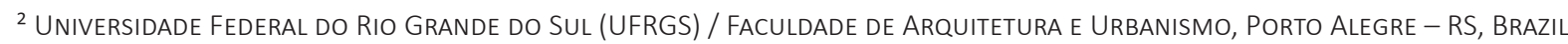

\begin{abstract}
New ways of manufacturing and working transcend the traditional limits of space and time, (re)designing everyday life. This article explains how the axiomatic of capitalism, within the current labor configuration and under the notion of immaterial labor, enters the home environment - a space quintessentially related to privacy and intimacy. In order to identify, present and analyze symbolic forms related to the operation of the axiomatic of capitalism with regard to the home environment, this longitudinal exploratory study considers media outlets - used for the modulation of methods of consumption and production of material life - as one of the elements that disseminates the axiomatic of capitalism. In addition to collecting information, symbolical forms were taken from 120 issues (2006-2016) of Casa Cláudia, a publication in the architecture, decoration and design segments. The analysis, based on the Methodology of Interpretation indicated: (i) the (com)position and behavior of the topic in the magazine, and (ii) the (re)functionalization, profitability, and naturalization of the home environment for labor purposes. Both indicate the living-working pair as an axiom of the axiomatic of capitalism. Through this media outlet- with a stimulated, disseminated and dissimulated apprehension- the axiomatic of capitalism deems the living-working pair as an extension of capital/labor without constraints, even in the smallest and most unusual spaces of intimate life.
\end{abstract}

Keywords: Immaterial labor. Axiomatic of capitalism. Living-working.

\section{Morar-trabalhar e a axiomatização capitalista: um estudo baseado em mídia do segmento de arquitetura, dec- oração e design}

\section{Resumo}

Novas formas de produzir e trabalhar transcendem limites tradicionais de espaço e tempo e (re)desenham a vida cotidiana. Buscou-se responder como a axiomática capitalista, na atual configuração do trabalho sob a noção de trabalho imaterial, interfere no lar - espaço por excelência da privacidade e da intimidade. Para identificar, apresentar e analisar formas simbólicas relativas à operação da axiomática capitalista no âmbito do lar, o estudo exploratório longitudinal tomou a mídia - afeita à modulação de formas de consumo e produção da vida - um dos elementos que serve à propagação da axiomática capitalista. Da coleta de dados, tomou-se formas simbólicas veiculadas em 120 edições (2006-2016) de Casa Cláudia, mídia dos segmentos de arquitetura, decoração e design. A análise à luz da Metodologia da Interpretação mostrou dois eixos: (i) (com)posição do tema na revista, e (ii) (re)funcionalização, rentabilização e naturalização do lar para o trabalho. Ambos os eixos indicam o morar-trabalhar como mais um axioma da axiomática capitalista. Por meio da mídia - numa captura estimulada, disseminada e dissimulada - a axiomática capitalista tem no morar-trabalhar a extensão do capital/trabalho sem constrangimentos, até mesmo nos menores e mais inusitados espaços da vida íntima.

Palavras-chave: Trabalho imaterial. Axiomática capitalista. Morar-trabalhar.

\section{Habitar-trabajar y la axiomatización capitalista: un estudio a partir de los medios de comunicación del segmento de arquitectura, decoración y diseño}

\section{Resumen}

Nuevas maneras de producir y trabajar trascienden los límites tradicionales de espacio y tiempo y (re)diseñan la vida cotidiana. Se buscó una respuesta a la pregunta de cómo la axiomática capitalista, en la actual configuración del trabajo y desde la noción de trabajo inmaterial, interfiere en el hogar, espacio por excelencia, de la privacidad y la intimidad. Para identificar, presentar y analizar formas simbólicas relacionadas con la operación de la axiomática capitalista en el ámbito del hogar, el estudio exploratorio longitudinal consideró los medios de comunicación -acostumbrados a la modulación de formas de consumo y producción de la vida - como uno de los elementos que favorecen la propagación de la axiomática capitalista. De los datos colectados, se consideraron formas simbólicas difundidas en 120 ediciones (2006-2016) de Casa Cláudia, revista de los segmentos de arquitectura, decoración y diseño. El análisis bajo la Metodología de la Interpretación mostró dos ejes: (i) (com)posición y comportamiento del tema en la revista y (ii) (re)funcionalización, rentabilización y naturalización del hogar para el trabajo. Ambos ejes indican que el habitar-trabajar es otro axioma más de la axiomática capitalista. A través de los medios (en una captura estimulada, difundida y disimulada), la axiomática capitalista considera que el habitar-trabajar es la extensión del capital/trabajo sin constreñimientos, incluso en los espacios más pequeños e insólitos de la vida íntima.

Palabras clave: Trabajo inmaterial. Axiomática capitalista. Habitar-trabajar. 


\section{INTRODUCTION}

Considering the intensification and overflowing of work (DAL ROSSO, 2012), the present study associates the axiomatic of capitalism (DELEUZE and GUATTARI, 2004; HUR, 2015) and immaterial labor (GORZ, 2005; LAZZARATO and NEGRI, 2001) and argues that such association allows us to identify new axioms that modulate ways of living regarding the unlimited advance of capital / labor.

The axiom theory, or axiomatic of capitalism, contributes to understand the way "[...] capitalism engages in a kind of 'management' [...] where it tries both to foster its expansion and to impose limits on it" (GUÉRON, 2017, p. 259). Both globally and locally, the axiomatic of capitalism becomes ubiquitous in a way that modulates behavior and being. Instead of one more code, there emerges a "[...] mode of operation, an immaterial, a combinatorial scheme that resonates, reverberates, and multiplies in every instance of life" (HUR, 2015, p. 166), fostering a capitalistic subjectivity relative to immaterial labor, which accompanies the individual in constant mobilization.

New ways of producing and working - teleworking, networking, projects and labor on demand - transcend traditional spatiotemporal boundaries, surprisingly (re) draw everyday life, illustrate that the inside and the outside no longer differ and "[...] everything is school, everything is business, everything is family" (PELBART, 2000, p. 30).

From this perspective, not even the house/home, the space of privacy, par excellence, a refuge for relaxing, protection, family stronghold, affection, is spared from the intensification and overflowing of work. Hybrid spatialities, a post-wall architecture (ELEB, 2011; MENDONÇA, 2010; TRAMONTANO and REQUENA, 2007), reinforce that the house/home has been invaded by elements that do not concern its intimate nature. Given this, we wonder: How does the axiomatic of capitalism, in the current configuration of work under the notion of immaterial labor, interfere in the house/home? In order to identify, present and analyze symbolic forms related to the operation of the axiomatic of capitalism in the house/home, we considered the relevance of the media to the study, because (i) beyond the dissemination of products, it is adapted by the modulation of forms of consumption and production of life to the taste of the market (BAUER and AARTS, 2002); and (ii) by circulating symbolic forms, it produces meanings and shapes ways of being, thinking and acting (THOMPSON, 2005). It was taken as database the Brazilian magazine Casa Cláudia - an exponent of the architecture, decoration and design media segment - from July 2006 to June 2016, in which immaterial labor is already seen as a source of profitability and competitiveness. Two axes of analysis (i) (com)position of the theme in the magazine, and (ii) (re)functionalization, monetization and naturalization from home to labor - pointed to the living-working axiom.

This study is divided into four sections: theoretical framework, methodological review, results and conclusion.

\section{THEORETICAL FRAMEWORK}

Along with the disciplinary society, we see the continually demanded and segmented individuals - family, school, factory - so each segment represents an episode. "Sometimes the different segments refer to different individuals or groups, sometimes it is the same individual or the same group that passes from one segment to another" (DELEUZE and GUATTARI, 1996, p. 84). The factory, the production space par excellence, is intended for machinery, the production line; the house/home is for the stronghold of privacy and intimacy, the bonds of family, affection, memories. Set up with walls that delimited functions and sectors, the house/home was a sanitary space and a place of energy replacement for work (CORREA, 2004). The notion of comfort sought to transform it into a sanctuary, refuge of harmony and healthy living of family members (ELEB, 2011).

Factory and house/home corresponded to each other in the logic of segmentation that characterized both and distinguished producers and consumers. The factory is distinguished according to the nature of the work and the operations, the house/ home according to the destiny of its rooms (DELEUZE and GUATTARI, 1997) in service, social and intimate sectors to even praise the passage that takes the individual from one episode to another. At home, the individuals would find themselves "[...] beyond the reach of factory discipline" (HARDT, 2000, p. 368). In this context of boundaries between the factory and the house/home, the immobility of labor/worker and capital is emphasized. 
In the transition from disciplinary to controlling society, "[...] the walls of institutions collapse, so that it is impossible to distinguish what is outside and inside" (HARDT, 2000, p. 369). Codes/forms/formats/norms acquire other appearances by virtue of a mode of operation that no longer sectorizes and immobilizes as described above.

A new production-consumption relation is configured in the fluidity of borders, in the distancing of spatiotemporal patterns from the Fordist production model, and in the possibilities arising from information and communication technologies, which allow the management controls to be extended over moving individuals. It is consistent with the intensification of work that refers to "[...] processes of any kind that result in greater expenditure on the physical, cognitive and emotional capacities of the worker with the aim of quantitatively increasing or qualitatively improving results" (DAL ROSSO, 2012, p. 23). In the form of network and flow, labor liberates capital that, without space-time limits, takes on family and social relations, and reaches ways of living - circulating, playing, studying, inhabiting.

Such processes favor the hegemony of immaterial labor (GORZ, 2005; LAZZARATO and NEGRI, 2001), which "[...] is fundamentally a performance: the product is the act itself" (HARDT and NEGRI, 2005, p. 261). This results in material and immaterial goods - information, affection, anticipation and problem solving, care, comfort, safety, satisfaction - through cultural baggage, proactivity, flexibility, tying the individual to the logic of total availability of self to work, where "[...] one must 'give' or 'surrender' continuously to this flow management; one has to produce themselves as a subject to assume it"(GORZ, 2005, p. 17).

About the worker, it is said that:

[...] There are many ways to save your honor and your soul. In order to subtract a part of their lives to full application at work, the 'workers of the immaterial' give to playful, sporting, cultural and associative activities, in which self-production is their own purpose, an importance that ultimately surpasses that of work (GORZ, 2005, p. 23).

Advertisers, stylists, artists, architects, designers exemplify workers who satisfy consumer demand while constituting it by sharing this logic of production-consumption. "The fact that immaterial labor produces both subjectivity and economic value demonstrates how capitalist production has invaded all life" (LAZZARATO and NEGRI, 2001, p. 47). Although the term immaterial is considered wrong - even by its authors -, since the work called in this way also has an inherent materiality, the phenomenon it names remains very important, even decisive, for understanding capitalist transformations in the last 40 years.

Immaterial labor proliferates in telework, project work and on-demand work, executable in flexible spaces and times, and is associated with the idea of hybrid spatialities, of a post-wall architecture (ELEB, 2011; MENDONÇA, 2010; TRAMONTANO and REQUENA, 2007). In their study, Tramontano and Requena (2007, p. 538) even warned that individuals tend to "[...] assume functions of production, editing and transmission of messages, previously reserved to third parties, which could be disseminated through blogs/flogs, or composing complex, eventually marketable products" within house/home. The expansion of social networking and the sophistication of gadgets reinforce their observation.

Enlarging spans, suppressing walls and rooms (AMORIN, GRIZ and LOUREIRO, 2011; FERREIRA, 2015) are highlighted in projects of developers, and media materials seem to overcome the need for constructive economics to meet post-wall desires to make space, sensorial and physically, broader, versatile and dynamic (FONSECA JORGE, 2013).

Operating in the material and immaterial, the axiomatic of capitalism reaches the most diverse instances of life - economic, political, affective, cognitive, in a capitalistic subjectivity. With Deleuze and Guattari (1997, p. 202) it is worth remembering that capitalism "[...] no longer operates as much through a quantity of labor as through a complex qualitative process that relativizes modes of transport, urban models, the media, the entertainment industry, the ways of perceiving and feeling" (emphasis added). Thus, the axiomatic modulates "[...] the behaviors in the same incessant march of the logic of productivity, even though they may acquire the most different clothes [...]. The format is replaced by the operation; forms change, but the axiomatic of capital remains the same" (HUR, 2015, p. 166-167). By replacing broken codes with a combinatorial one, the axiomatic "[...] captures at one end what it loses at the other" (DELEUZE, 2005, p. 105).

In this way, if something escapes, new axioms are added in continuous/unceasing processes of creation-production-consumptionincorporation. The axiomatic is redone through an operation - displacement/sliding/hybridization - that configures not only the expansion of the limits of capital, but their very own dilution (DELEUZE and GUATTARI, 1997; GUÉRON, 2017; HUR, 2015) through immaterial labor (GORZ, 2005; LAZZARATO and NEGRI, 2001). Capitalism, thus, differs from the social relations of production that matched the codification of the flows of desire, and operates from an axiomatization system. 
Although it operates on a global scale, it is imperative for the axiomatic of capitalism to operate on a local scale "[...] to ensure its reproduction and to shift its boundaries. The fact that capitalism seeks to embrace the vital question at these two extremes or levels makes the current situation even more desperate" (SANTOS, 2000, p. 420). Thus, it can be seen that:

[...] more elaborate lifestyles must be represented as universally available if they are to be successfully introduced to the market. Its supposed accessibility is the necessary condition for its ability to seduce. They inspire buying motivations and consumer interest because potential buyers believe the models they are looking for are attainable. Moreover, they should be admired so that they are legitimate objects of practical action and not just respectful contemplation (BAUMAN and MAY, 2010, p. 253).

It is necessary to consider the affluence and the influence of the media in the production of meanings, which is pointed out by texts and/or images related to what is thought, spoken, felt and practiced about a theme (BAUER and AARTS, 2002; THOMPSON, 2005). Mainly because "[...] the axioms of capitalism are not evidently theoretical propositions, nor ideological formulas, but operative statements [...] that enter as component parts in the production, circulation and consumption agencies" (DELEUZE and GUATTARI, 1997, p. 163), promoting, encouraging, reinforcing a lifestyle and a consumerist existential strategy (BAUMAN, 2008).

It is in this sense that media materials circulate "[...] complex symbolic constructions, to which something is expressed or said. Symbolic forms are contextualized products and something else that, by virtue of their structural characteristics, have capacity, and aim to say something about something" (THOMPSON, 2005, p. 369). Media materials prove to be crucial to the propagation of axiomatic of capitalism, as they "have [...] in the mind of the individual an even more important effect than their own immediate reality, becoming 'virtual reality', that is, the media tends to surpass and anticipate the event, before it actually becomes a reality" (DOREA, 2002, p. 101). It is in the multiplicity of its operators, of the means by which it operates, that there is no room for dissent "[...] regarding the way of life established by capitalism" (DOREA, 2002, p. 102).

This study collects and analyzes data from media concerning architecture, decoration and design segments because it shows symbolic forms that produce meanings and shape ways of being, thinking and acting (THOMPSON, 2005) towards home.

\section{METHODOLOGICAL REVIEW}

Given the proposed objective and the lack of studies in the same direction, a longitudinal exploratory study was chosen, considering altogether: (i) the procedural and permanent character of the axiomatic of capitalism; (ii) the media as one of the ways in which the axiomatic operates; and (iii) the legitimacy of the use of media as a field (ITUASSU and TONELLI, 2014; RODRIGUES, MORIN and STREHLAU, 2009). We opted for the magazine Casa Cláudia considering its content (production), national coverage (circulation) and reach in number of readers (reception).

Its content corresponds to symbolic forms (THOMPSON, 2005) that have some kinds of aspects like: intentional (they are expressions of one subject to another - presents, anticipates, suggests to readers actions related to architecture, decoration and design); conventional (its construction, its use, and the interpretation by its recipients refer to processes involving rules and conventions of various kinds - readers are introduced to a production that starts with a monthly agenda); structural (they show articulated structure - cover, summary, editor's letter, body); referential (they necessarily refer to something and say something about something - house/home); and contextual (they are inserted in contexts and socio-historical processes, in which and by which they are produced, transmitted and received - immaterial labor).

The magazine presents itself as the "[...] largest and best decoration and design magazine in Brazil" (CASA CLÁUDIA, 2018, p. 1). In 2017, after its 40th anniversary, it reached 1.1 million readers, both for print and digital material, two million followers on Facebook and 970,000 on Instagram. Its target audience is female (81\%) - women over 30 (87\%) - from classes A and B (66\%) with an interest in architecture, decoration and design (47\%) and / or that claims to build / renovate in the short term (48\%). Monthly it shares inspiring stories, "practical information for people to take refuge in their dreams, considering personal history, lifestyle and budget” (CASA CLÁUDIA, 2018, p. 1). 
Data collection took place through extensive search in private libraries, magazines and bookstores. We gathered 120 print issues of the magazine - from July 2006 to June 2016. Once they were chronologically organized and thoroughly read, we have put the total of the content provided in an Excel spreadsheet, considering the symbolic forms in which they have "[...] written, spoken, mapped, figuratively drawn and/or symbolically explicit" (MINAYO, 2003, p. 74). In the formation of the body of analysis, attention was paid to the text and/or image, and a priori we considered terms commonly associated with dwelling and working - office, work/working at home, home office - to which, a posteriori, those that emerged in the magazine - workstation, work / computer corner, home-studio, home-office, kitchen-laboratory - as well as elements related to the residents' lifestyle - stories, memories and professional activities, were added. Occurrences associated with children and / or adolescents were not considered.

Based on the Interpretation Methodology (THOMPSON, 2005), this study connects: the context of immaterial labor with a socio-historical analysis; the composition of the elements of dwelling and working from symbolic forms with formal analysis; the interpretation of editors, journalists, photographers of the magazine, already expressed in the texts and / or images with the (re)interpretation or "creative construction of possible meanings" (THOMPSON, 2005, p. 375).

From the connections undertaken, we could identify two axes of analysis: (i) (com)position of the theme in the magazine; and (ii) (re)functionalization, monetization and naturalization of the house/home for the work. The occurrences analyzed were chosen according to their representativeness in the elaboration of symbolic forms of dwelling/working.

\section{RESULTS}

\section{The (com)position of the magazine theme}

Made with a material that is pleasing to the touch, colloquial texts and abundant photographs, the magazine seduces when it is being handled. Numerous possible entries emerge as one scans its pages, anticipating a glimpse into the identification/ (com)position of the theme in Casa Cláudia. It was found that a single term - office - was used to designate both an isolated and exclusively work-oriented room as a bedside table in a double room. Other highlights include unusual places to designate and allocate work space, such as: home-office, home-studio, kitchen-laboratory, hybrid space, entrance hall, hallway and headboard.

The dwelling-working theme was identified both by paying attention to what was so explicit that one gets easily used to it, as to what is interfering with something implicit, which at first does not concern it, demanding intensified attention while glimpsing or seeing something. Therefore, the following (com)position takes it from several prisms.

Initially, 448 occurrences of the dwelling-working theme were mapped. In an oscillating way, they were continuously distributed in the 120 issues of the magazine (Graph 1).

Graph 1

Distribution of Occurrences

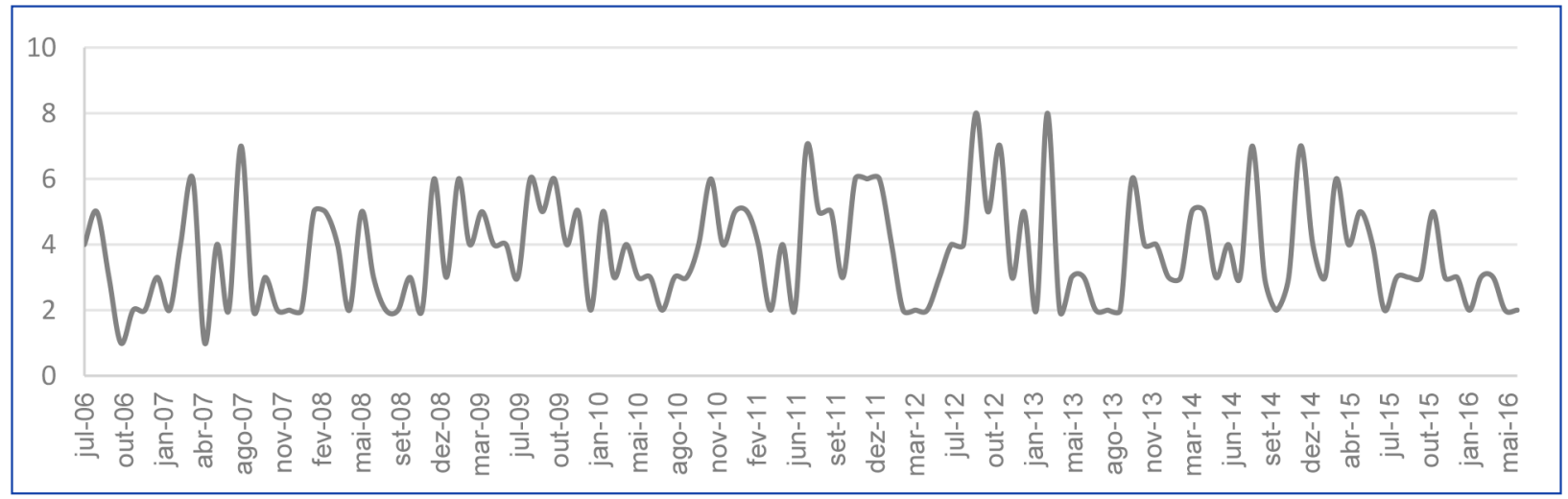

Source: Elaborated by the authors. 
Once the distribution of occurrences was verified, we sought to see their location and mode of presentation in the magazine's structure. For the 150 located on the Cover, Editor's Letter and Summary, given its character as advertisement, it was considered an Announced occurrence (A) - the subject being evident, explicit in one or the other. For the 298 located in the Body - as articles -, it was considered an Non-announced occurrence (N) (Box 1) - corresponding to all articles in which the theme, explicitly or not, is present in the magazine's body.

\section{Box 1}

Theme mapping

\begin{tabular}{|c|c|c|c|}
\hline \multirow{2}{*}{ Presentation } & \multicolumn{2}{c|}{ Localization } \\
\hline \multirow{2}{*}{ Announced (A) } & \multirow{2}{*}{$150(33,5 \%)$} & Cover & $43(9,6 \%)$ \\
\cline { 3 - 4 } & & Editor's Letter & $17(3,8 \%)$ \\
\cline { 3 - 4 } & & Summary & $90(20,1 \%)$ \\
\hline Non-announced (N) & $298(66,5 \%)$ & Body & $298(66,5 \%)$ \\
\hline Total & & $448(100 \%)$ \\
\hline
\end{tabular}

Source: Elaborated by the authors.

What is announced (33.5\% recorded occurrences) has greater visibility and indicates greater relevance attributed by the magazine. Each issue, considering the structure, allows a combinatory regarding the Announced (A) and Non-announced (N) occurrence (Box 2).

\section{Box 2}

Theme mapping - Announced (A) e Non-announced ( $N$ )

\begin{tabular}{|l|c|c|c|c|c|c|c|c|}
\hline \multicolumn{1}{|c|}{ Localization } & \multicolumn{7}{|c|}{ Presentation } \\
\hline Cover & A & A & A & A & N & N & N & N \\
\hline Editor's Letter & A & A & N & N & A & A & N & N \\
\hline Summary & A & N & A & N & A & N & A & N \\
\hline Number of issues & 10 & 3 & 21 & 2 & 3 & 1 & 31 & 49 \\
\hline \multicolumn{10}{|c|}{ Total } & \multicolumn{7}{|c|}{120} \\
\hline
\end{tabular}

Source: Elaborated by the authors.

Of the eight possible combinations, four stood out for their repetition in the issues - NNN (49); NNA (31); ANA (21); AAA (10). Overall, it shows that: (i) the visibility and relevance attributed to the theme - ANA (21) and AAA (10) - are concentrated in the first half of the analyzed period (Figure 1); (ii) in 80 issues, the occurrences related to the theme were not announced, or were only in the Summary - NNN (49) and NNA (31) (Box 2) - suggesting that, over the period, the theme does not require advertisement.

Figure 1

Theme mapping - presentation over the period

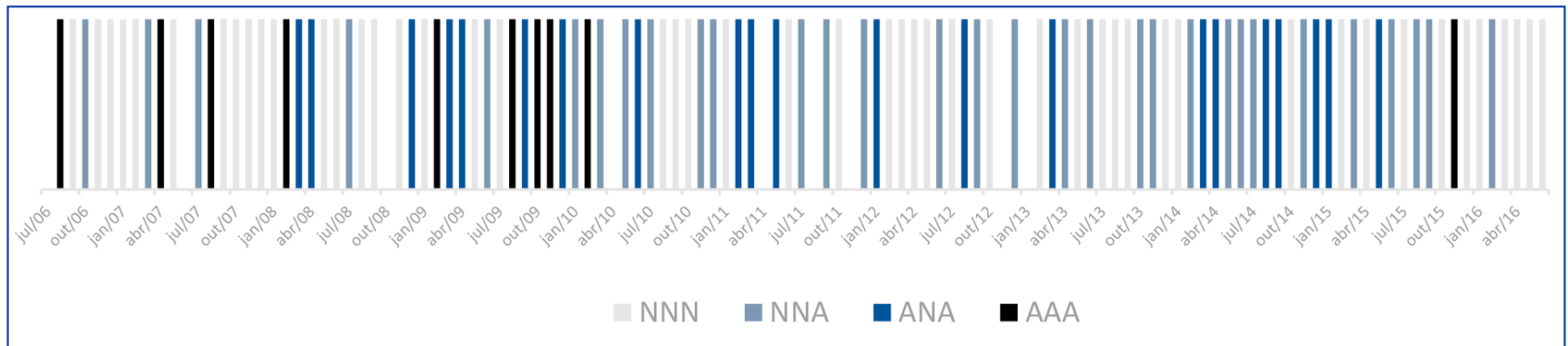

Source: Elaborated by the authors. 
The axiomatic of capitalism is constituted and maintained precisely in the glimpse or the view regarding the identification and (com) position of the dwelling-working theme over the period in terms of a combinatory Announced - Non-announced. It operates in / by displacing the theme in the structure of the magazine in all issues, which thus resonates, reverberates and multiplies in symbolic forms (HUR, 2015; THOMPSON, 2005). Box 3 exemplifies two combinators that show the nuances of the presence / visibility of the theme.

\section{Box 3}

Presence of the theme - structure of the magazine

\begin{tabular}{|c|c|c|c|}
\hline \multicolumn{4}{|c|}{ Combinatory AAA - Casa Cláudia (Feb./2008) } \\
\hline Cover $(\mathrm{A})$ & Letter $(A)$ & Summary (A) & Article \\
\hline $\begin{array}{l}\text { "Discover the advantages } \\
\text { of WORKING AT HOME. } 5 \\
\text { professionals tell how they } \\
\text { adapted the decoration } \\
\text { and the domestic routine" } \\
\text { (Secondary Headline). }\end{array}$ & $\begin{array}{l}\text { "The article A Space to Live and } \\
\text { Work reports the experience of } \\
\text { two people from São Paulo and } \\
\text { three from Rio de Janeiro who } \\
\text { opted for a professional routine } \\
\text { with less traffic wear and more } \\
\text { hours to devote to their families." } \\
\text { (FARIAS, 2008, n.p.). }\end{array}$ & $\begin{array}{l}\text { "A Space to Live and Work. } \\
\text { See how five professionals } \\
\text { have transformed home into } \\
\text { their workplace and adapted } \\
\text { the house routine." }\end{array}$ & $\begin{array}{l}\text { "A space to live and work. They do } \\
\text { not face traffic and have more time } \\
\text { flexibility and day-to-day comfort. } \\
\text { See how five professionals have } \\
\text { adapted the routine and decoration } \\
\text { to keep the house as an ally of } \\
\text { work." }\end{array}$ \\
\hline \multicolumn{4}{|c|}{ Combinatory NNN - Casa Cláudia (Oct./2013) } \\
\hline Cover $(\mathrm{N})$ & Letter $(N)$ & Summary (N) & Article \\
\hline $\begin{array}{l}\text { "THE BEAUTY OF SIMPLE } \\
\text { THINGS. It doesn't take much } \\
\text { for home life to be more } \\
\text { enjoyable." }\end{array}$ & $\begin{array}{l}\text { It makes no mention of the article } \\
\text { in question. }\end{array}$ & $\begin{array}{l}\text { "A look at the simple things. } \\
\text { Stripped-down styles of } \\
\text { living, in which beauty comes } \\
\text { from small details, memories } \\
\text { and even imperfections." }\end{array}$ & $\begin{array}{l}\text { "The idea of uncomplicating } \\
\text { routine involves being open to } \\
\text { change and balancing work and } \\
\text { pleasure." }\end{array}$ \\
\hline
\end{tabular}

Source: Elaborated by the authors.

The (com)position of the theme also has specificities regarding the Cover - Main and Secondary Headlines, Editor's Letter, Summary and Body (Graphs 2, 3, 4 and 5).

Graph 2

Theme (com)position - Cover (A)
Graph 3 Theme (com)position - Editor's letter (A)

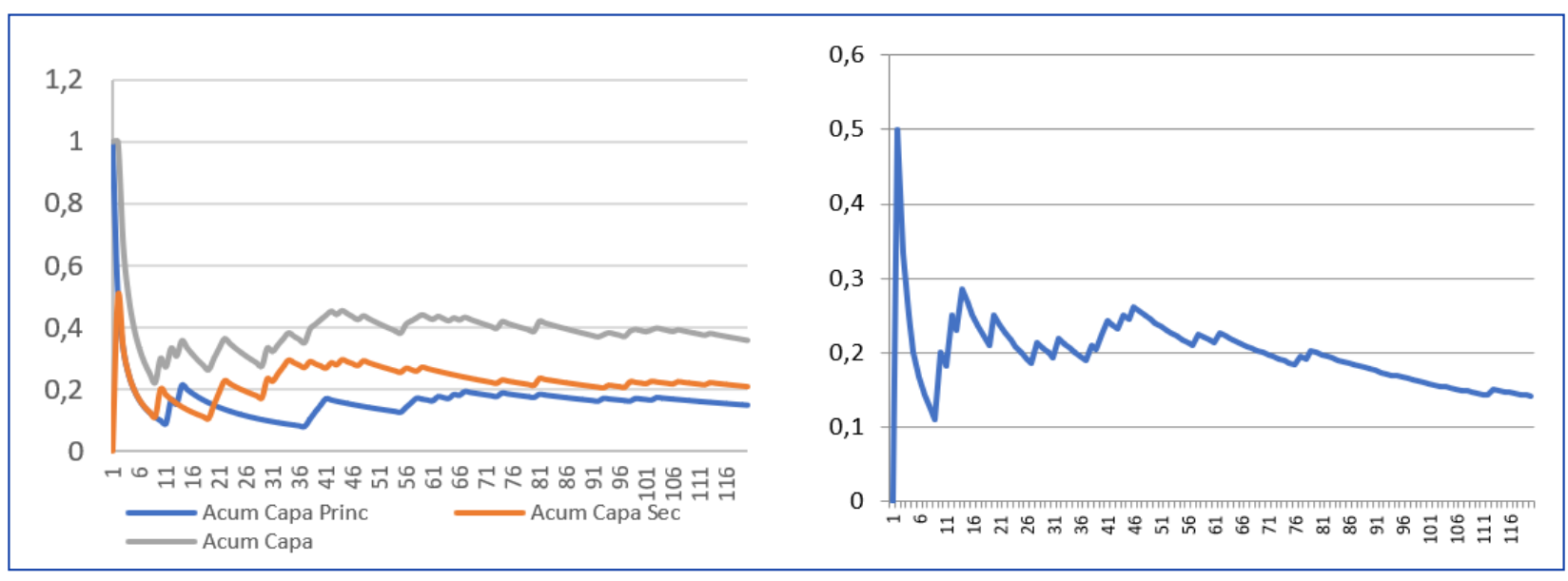

Source: Elaborated by the authors. 
Graph 4

Theme (com)position - Summary $(A)$
Graph 5

Theme (com)position - Body (N)

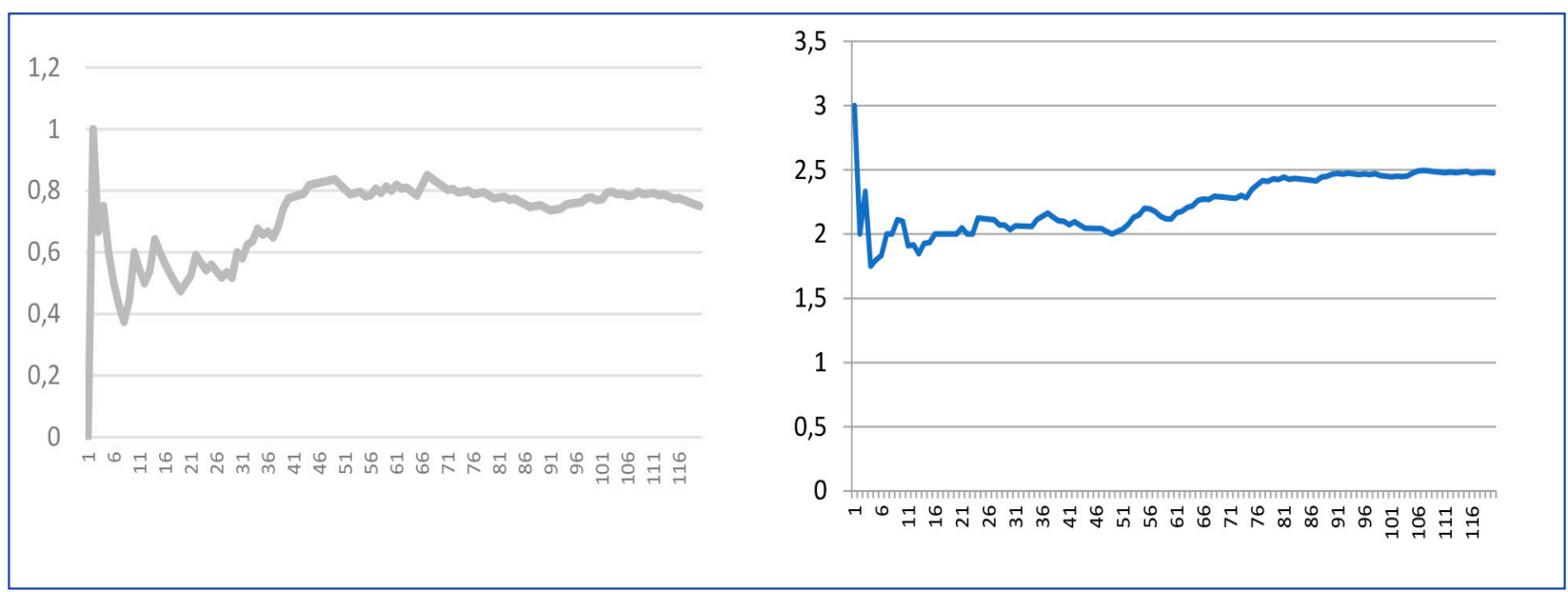

Source: Elaborated by the authors.

The four graphs show that, as the theme presence decreases in the Cover, Editor's Letter and Summary, it increases in the Body of the magazine as Non-announced occurrence, suggesting the assimilation of the house/home as a workspace. If the notoriety given to the theme in the form of advertisement is gradually let up in the magazine throughout the period, it is because it has already become naturalized. There being no more dissent regarding the established way of life (DOREA, 2002), the announcement of dwelling-working may be not necessary. Cover, Editor's Letter, and Summary have more peculiarities (Box 4).

Box 4

Distribution of occurrences in the Cover, Editor's Letter and Summary

\begin{tabular}{|l|l|c|}
\hline \multicolumn{2}{|c|}{ Localization } & Number of Occurrences \\
\hline \multirow{2}{*}{ Cover } & Main Headline & 18 \\
\cline { 2 - 3 } & Secondary Headline & 25 \\
\hline \multicolumn{2}{|c|}{ Editor's Letter } & 17 \\
\hline Summary & Total & 90 \\
\hline \multicolumn{2}{|c|}{} & 150 \\
\hline
\end{tabular}

Source: Elaborated by the authors.

In Casa Claudia, each Cover has a unique Main Headline, which stands out in terms of size, position, color and type of font used in relation to the Secondary one. Distributed in 36 Covers (30\% of the total issues), the 43 occurrences of Cover - 18 Main and 25 Secondary Headlines - attest to the relevance that the magazine attributed to the theme. The 18 Main Headlines corresponding to 18 issues (15\% of the total issues) are, proportionally, even more expressive than the Secondary ones, due to their lower possibility of occurrence in the place of more visibility and notoriety that content may have in the magazine. Box 5 and Box 6 show some Cover Headlines of the period. 
Box 5

Theme - Main Headline

\begin{tabular}{|c|l|}
\hline $\begin{array}{c}\text { Casa Cláudia } \\
\text { Issue }\end{array}$ & \multicolumn{1}{c|}{ Main Headline } \\
\hline Aug./07 & $\begin{array}{l}\text { "The rooms are now multipurpose for living, dining, watching TV, working and studying. See } 3 \\
\text { projects with 11, 46 and 50m". }\end{array}$ \\
\hline Oct./09 & $\begin{array}{l}\text { "Use your room well. Get inspired in spaces designed to comfortably receive guests, watch TV, } \\
\text { work, play with friends...". }\end{array}$ \\
\hline Nov./09 & "Live with style. Flexible decoration for living and working in 79m". \\
\hline Apr./11 & "23 solutions for small apartments. 85m² couple receives guests and works in the social area". \\
\hline Aug./11 & "How nice to live at home ... With backyard, office in the shed and space for children and animals". \\
\hline Mar./13 & "Enjoy your home! Beautiful rooms to really use: receive guests, work, watch TV and even cook". \\
\hline Jan./15 & "House in order. Experts show the tricks that organize closet, kitchen and office. \\
\hline
\end{tabular}

Source: Elaborated by the authors.

The Main Headlines associate the term work with multifunctionality - multipurpose rooms; with action - to work; they refer to objects to work - desk; the home workspace - office; they urge action to work with imperatives - see, give, use, inspire, change, and enjoy. The work action is associated with the novelty - the rooms are now multipurpose; with monetizing the domestic space - using the room well or using it for real; and with style - flexible decoration. An object of explicit use to work is aligned with the idea of decoration and comfort items; and home workspace is aligned with the ideas of technology and organization.

\begin{tabular}{l} 
Theme - Secondary Headline \\
\begin{tabular}{|c|l|}
\hline $\begin{array}{c}\text { Casa Cláudia } \\
\text { Issue }\end{array}$ & \multicolumn{1}{c|}{ Secondary Headline } \\
\hline Aug./06 & "Bookcases, tables, benches and sliding doors make it easy for those who work at home". \\
\hline Apr./07 & $\begin{array}{l}\text { "Where to put the computer. 4 work corners and a reversible workbench to assemble without } \\
\text { spending too much". }\end{array}$ \\
\hline Feb./08 & "Discover the benefits of WORKING AT HOME". \\
\hline Feb./10 & "Computer corner: in the lobby, living room and bedroom". \\
\hline Feb./11 & "Work at home. 5 racking environments and 12 furniture options". \\
\hline Aug./12 & "Is your office also a guest room? See how to make it beautiful and organized". \\
\hline Mar./13 & "A warehouse in downtown Fortaleza becomes a bright studio house". \\
\hline Mar./13 & "Mobility is everything. New technologies change the way we work at home". \\
\hline Mar./14 & "Slow down. Get inspired by the artist who can live quietly in the metropolis (and her house is wonderful)". \\
\hline Nov./15 & "Delicious lunch. Get inspired by chef Renata Vanzetto's way of welcoming her friends with charm \\
and relaxation".
\end{tabular} \\
\hline
\end{tabular}

Source: Elaborated by the authors.

Secondary Headlines refer to the facilitations and advantages of homeworkers; the possibility of choices; the enlargement of the names associated with the workspace - work corner, computer corner, home studio; and the lifestyle related to the way you receive your guests. 
They refer to the work action and the house/home workspace. The work action is associated with everyday facilities, advantages, diverse furniture options and mobility. The object that was used exclusively for the work leaves the scene and is converted into benches and multifunctional shelves. House/home workspace aligns with technology, the idea of low cost, reversibility, the unusual use of space under the stairs and the lobby.

The Secondary Headlines also refer to the residents in terms of profession - chef and artist; and identification- first and last name. By presenting residents who reconfigured their house/home for work and shared their styles of living and receiving guests with readers, the new production/consumption relationship and the profitability of house/home and self for work are praised (LAZZARATO and NEGRI, 2001).

Approaching the Main and Secondary Headlines, in the first issues it is observed that the Main one points out novelties regarding the multiplicity; and the Secondary one shows the advantages and facilitations ahead. In the final editions, the Main Headlines focus on optimizing the reconfigured home for work; and the Secondary ones for the change in the way of working at house/home, as well as for the presentation of residents and their professions, something that was not mentioned in any of the Main Headlines.

The Editor's Letter sets the tone for each issue, announcing and highlighting the content to come. The presence of the theme is found in excerpts of 17 Letters ( $14 \%$ of the total Letters analyzed) signed by three editorial managers that intersect over the period. It is noteworthy that 13 of them are concentrated in the first half of the period (Box 7).

Box 7

Theme - Editor's Letter

\begin{tabular}{|c|c|}
\hline $\begin{array}{l}\text { Casa Cláudia } \\
\text { Issue }\end{array}$ & Occurrence \\
\hline Aug./06 & $\begin{array}{l}\text { "And if the question is to reformulate your work corner, be inspired by the ideas } \\
\text { shared by } 6 \text { professionals." (FARIAS, n.p.). }\end{array}$ \\
\hline Apr./07 & $\begin{array}{l}\text { "You find out how computer space becomes a functional and pleasant corner } \\
\text { even when the room is inches away and the monitor is in the bedroom on the } \\
\text { side table of the bed." (FARIAS, n.p.). }\end{array}$ \\
\hline June/07 & $\begin{array}{l}\text { "The challenge for future residents is that the reduction of square meters coexists } \\
\text { with the aspiration (and the need) to have at home environments prepared for } \\
\text { leisure and work." (FARIAS, n.p.). }\end{array}$ \\
\hline Aug./07 & $\begin{array}{l}\text { "Today, the term in vogue for the social area is 'multipurpose room'. This means } \\
\text { that the space- often small- must be prepared for various functions: receiving } \\
\text { guests, watching TV, working, studying, dining... And, the most interesting, these } \\
\text { activities can occur simultaneously, hence the questions arise: how to work in the } \\
\text { same territory in which children play? [...] Another room has a balcony adapted } \\
\text { to receive the office." (SANTANA, n.p.). }\end{array}$ \\
\hline Feb./08 & $\begin{array}{l}\text { "The article A Space to Live and Work reports the experience of two people from } \\
\text { São Paulo and three from Rio de Janeiro who opted for a professional routine } \\
\text { with less traffic wear and more hours to devote to their families." (FARIAS, n.p). }\end{array}$ \\
\hline Oct./08 & $\begin{array}{l}\text { "Testimonials from five professionals about the revolution that the ecological } \\
\text { movement provoked in each one's work and lifestyle" (FARIAS, n.p). }\end{array}$ \\
\hline Feb./09 & $\begin{array}{l}\text { "The projects fulfill many wishes: from lamps for those who love reading in bed } \\
\text { to the discreet workbench." (FARIAS, n.p). }\end{array}$ \\
\hline Aug./09 & $\begin{array}{l}\text { "A desk by the sofa and the dresser that migrates into the living room are some } \\
\text { examples of finely tuned compositions you discover from page } 60 \text { onwards" } \\
\text { (FARIAS, n.p.). }\end{array}$ \\
\hline Oct./09 & $\begin{array}{l}\text { "Environments put aside any doubts. The room has become the place where } \\
\text { everything happens: watching TV, studying, working, accessing the internet, } \\
\text { receiving guests." (FARIAS, n.p.). }\end{array}$ \\
\hline Nov/09 & $\begin{array}{l}\text { "How is it possible to create environments in tune with our emotions and tastes } \\
\text { and circumvent issues such as smaller spaces, high costs, work at home, new } \\
\text { family groups, technology, sustainability?" (FARIAS, n.p). }\end{array}$ \\
\hline
\end{tabular}


Living-working and the axiomatic of capitalism: a study based on media outlets in the architecture, decoration, and design segments
Ana Carolina dos Santos Bortolini

Carmem Ligia Iochins Grisci Ana Elísia da Costa

Continue

\begin{tabular}{|c|c|}
\hline $\begin{array}{l}\text { Casa Cláudia } \\
\text { Issue }\end{array}$ & Occurrence \\
\hline Feb./10 & $\begin{array}{l}\text { "Everything I did best in my life, I envisioned while sleeping. The last scenario of } \\
\text { the parade for Chanel, I didn't look for. I don't know where it came from. I woke } \\
\text { up with those images. That's why I always have a sketchbook next to my bed } \\
\text { [...] That the privilege of living in an environment in tune with your style is your } \\
\text { deserved prize in 2010." (FARIAS, n.p.). }\end{array}$ \\
\hline Apr./10 & $\begin{array}{l}\text { "It created a unique environment, capable of evoking the playful feeling Adriana } \\
\text { enjoys in her professional activity: producing delicious sweets that resemble } \\
\text { design objects." (FARIAS, n.p). }\end{array}$ \\
\hline Apr./11 & $\begin{array}{l}\text { The spaces of our home quickly reinvented themselves to meet the countless } \\
\text { demands of contemporary life- do you remember when a computer per home } \\
\text { was a more than satisfactory account?" (FARIAS, n.p.). }\end{array}$ \\
\hline Aug./11 & $\begin{array}{l}\text { "Small pleasures like these and others- growing flowers, having a vegetable garden, } \\
\text { turning the shed into a studio and the garage into a workshop..." (SANTANA, n.p.). }\end{array}$ \\
\hline Nov./12 & $\begin{array}{l}\text { "Walking through four different style trends (named Bucolic Refuge, Deep Romantic, } \\
\text { Organic Intimate, and House-Studio), we came to the conclusion that the need } \\
\text { to create a private and sustainable nest where we can impress our personality } \\
\text { is the common feature of our times." (SANTANA, n.p.). }\end{array}$ \\
\hline Jan./13 & $\begin{array}{l}\text { "Like normal human beings- who live surrounded by objects, books and documents } \\
\text { - they create practical, easy-to-copy solutions that keep beautiful rooms, kitchens } \\
\text { and offices with everything in its place." (SANTANA, n.p.). }\end{array}$ \\
\hline Nov./15 & $\begin{array}{l}\text { "Architects no longer use the idea of a room- they think more about the usability } \\
\text { of space. Office, kitchen, living and dining rooms, TV ... Even the bedroom is not } \\
\text { just seen as a sleeping environment. [...]. Kitchen-living room, bedroom-office, } \\
\text { balcony-living room and even bedroom-bathroom are already perfectly possible } \\
\text { combinations, showing that there is no distinction between work and leisure. All } \\
\text { together and mixed." (FERREIRA, n.p.). }\end{array}$ \\
\hline
\end{tabular}

Source: Elaborated by the authors.

The first Letters recognize uncertainties about the transformations related to work at home, something to be dispelled in light of the ideas and inspirations contained in the magazine. Technology, always emphasized, is taken as one of the triggering elements of the so-called accelerated changes, until its insertion in the house/home in order to reconfigure it, comes to a mere memory.

If centimeters are missing, given the increasing of tight spaces, the message is that there is nothing to worry about when working at home, as the environments become multifunctional. Given the readers' presumed needs and desires - combining leisure and work in small spaces - functional corners are indicated simultaneously for various tasks. The exploration of the multifunctionality of the rooms acquires an air of challenge and necessity, until such use becomes unquestionable and presented as a sign of the times.

If, at first, the Letters allude to the doubts, challenges, desires and benefits of residents supposedly in need of hosting work at home, in the end they indicate that everything - dinner, receiving guests, sleeping and even working in the same space as children play - is justified by the advantage of a routine with less wear and tear.

Regarding the new nomenclatures related to space and work objects in the house/home, the following stand out: computer space, multipurpose room, workbench, home-studio, bedroom-office.

The latest Letters refer to the theme only to emphasize the consolidation of the market and professionals in the field. The room which is assigned to a single function has been replaced by bedroom-office and bedroom-bathroom, referring to the idea of hybrid spatialities (TRAMONTANO and REQUENA, 2007) and indicating the (re)functionalization, monetization and naturalization of the house/home. 
All references to working at home are made positively and in a way that meets the interests of residents. They are related to novelty, leisure, family life, sustainability, less traffic wear and tear, lifestyle, beauty, sometimes enjoyable, sometimes advantageous, sometimes pleasant, sometimes practical and organized, sometimes playful.

If the Cover and Editor's Letter are readers' first contacts with the magazine, the Summary makes it easier for them to search for content. We identified 90 occurrences in the Summary, distributed in 65 issues (54\% of total). The text presented in the Summary indicating the presence of the theme does not always coincide with the text of the Cover Headlines and the title of the Body articles, and vice versa, as shown in Box 8.

\section{Box 8}

Theme - Summary according to the Cover

\begin{tabular}{|c|c|}
\hline Casa Cláudia (Jan./2010) & \\
\hline Cover $(\mathrm{N})$ & Summary (A) \\
\hline $\begin{array}{l}\text { "39 ideas for organizing the house. } \\
\text { Carpentry and accessory projects } \\
\text { put clothes, papers, crockery and } \\
\text { toys in order." }\end{array}$ & $\begin{array}{l}\text { "The pleasure of having the House in Order. Ideas and products to get rid of the mess of } \\
\text { the office, playroom, service area, paint studio and other environments in the house." }\end{array}$ \\
\hline \multicolumn{2}{|r|}{ Casa Cláudia (Mar./2013) } \\
\hline Cover (N) & Summary (A) \\
\hline $\begin{array}{l}\text { "Mobility is everything. New } \\
\text { technologies change the way we } \\
\text { work at home." }\end{array}$ & $\begin{array}{l}\text { "Work on the go. With portable appliances and new technologies, the home office can be } \\
\text { in any environment of the home." }\end{array}$ \\
\hline
\end{tabular}

Source: Elaborated by the authors.

Box 8 also illustrates how, over the observed period, the magazine's (com)position favored that the theme was glimpsed and seen for, even if non-announced, it could find itself mingled in another, which constitutes the next axis of analysis.

\section{(Re) functionalization, monetization and naturalization of the house/home for work}

Paying attention to the diversity of personal stories, lifestyles and the budget of its readers, the magazine strives to show something that can be achieved by all, a necessary condition for seduction and the guarantee of success in the market (BAUMAN and MAY, 2010). It even discloses the profession, objects and personal tastes of residents, their image and that of their families and pets; in short, it shows the way life is animated, even regarding work, in the context of the house / home presented.

The article 6 workspaces at home (CASA CLÁUDIA, Aug./2006) shows spaces specifically configured for work, different from those related to other domestic activities. As for the article How to revitalize the decoration. It was like this ... and it was like this! (CASA CLÁUDIA, Sept./2007), the office migrated to the dining room after the designer wondered about the confinement of work to the guest room, since it could be done in a more spacious and bright place, even favorable to the reception of customers. In addition, the environment which was designed in its reversibility can work as a day-to-day office and dining corner when needed.

The article 59 ideas for decorating small spaces (CASA CLÁUDIA, Oct./2007) shares a nutritionist's story and reproduces the floor plan of the construction that transformed two united bedrooms of her house into suite with an office. Powerful carpentry, in the same issue, illustrates how the headboard came to cover a desk. Even focusing on the carpentry work, the article alludes to the supposed guarantee of privacy, disregarding, therefore, that the work had already entered the intimacy of the house / home.

This is also observed in the article It looks like a gallery (CASA CLÁUDIA, Sept./2012), which portrays the house / home of an interior designer and an art dealer. With the subtitle Adaptations that life brings, the article reports that the office environment became a room with the arrival of the couple's daughter. As a result, the office became a little space between the sliding closet door and the bedside table. The tip for living quietly with the desk so close to the bed, according to the designer, is 
not to fill it with papers, which means not to problematize dwelling-working together, even if it occurs in tight spaces, as the diminutive "little space" indicates. According to the flow management of the axiomatic of capitalism (DELEUZE and GUATTARI, 2004; HUR, 2015), what is observed is the displacement / minimization of the precariousness of the situation.

In Discover the advantages of working at home (CASA CLÁUDIA, Feb./2008), it is reported how five professionals - an architect, a lawyer, an artist and two designers - adapted the routine and decoration to work on their own houses/homes. Advantages of working at home were pointed out: not facing traffic and having free time; spending more time with children and pets. On the other hand, taking the bag, turning off the lights and leaving the office; walking through the living room door and feeling at home; being twice as disciplined to not stay in pajamas all day long; having lunch outside so as not to eat badly; going for a walk in the evening and relax; taking a moment to rest are some of the methods, even childish ones, that are recommended not to succumb to the visible risks of dwelling-working.

Living with style (CASA CLÁUDIA, Nov./2009) associates work with flexible decoration, which is indicated as suitable for living and working. A camouflaged door enters the office; the ballerina's platform serves as a bed for guests; the folding doors take the place of walls; the arrangement of furniture and circulation in the environment assume various configurations, such as the work-configuration by providing computer spaces used by a team, and the gourmet-configuration for the reception of friends. Everything meeting the wishes of a hybrid home.

Design is forever (CASA CLÁUDIA, Sept./2012) portrays the house / home of a sales consultant and an administrator, it praises the freedom to change the function of spaces, considering, for example, that the sofa can change place, and that the heightadjustable dining table can turn into a bar or on office.

Beautiful rooms for real use, The artist's temple and Work on the move, which have as Cover Headline Mobility is everything (CASA CLÁUDIA, Mar./2013), highlight respectively: (i) multiple space by presenting the kitchen combined to the living room, dining room and library where the chef tests her blog and book recipes; (ii) a space called home-studio, where the architect / painter receives friends, works for hours and exposes his works to the public; (iii) presence of home office in any environment of the house/home, which becomes homeofficing from the perspective of an operation (HUR, 2015) that modulates the conduct and being within the house/home.

The attic as a stylish office, in Double dose of fun (CASA CLÁUDIA, Jan./2014); irreverent office in Design, Humor and Rock'n'Roll (CASA CLÁUDIA, Sept./2015); the colorful floor preserving the memory of the tones of a trip in Downtown (CASA CLÁUDIA, Apr./2016). The house/home adjusted for work is characterized by adjectives that refer to styles, affections, and memories, seen as mobilizer from the perspective of immaterial labor, and therefore productive.

It is noteworthy that the informed profession of the residents corresponds to the notion of immaterial labor (GORZ, 2005; LAZZARATO and NEGRI, 2001). All self-mobilizing activities beyond spatiotemporal boundaries are potentiated in the form of networks and flows and match with cultural activities from the perspective of cultural-informative-collaborative content - journalist, advertiser, photographer, executive producer of photograph, teacher, writer, art dealer, actor -; with manual activities intertwined with creativity, imagination and technical-manual work - architect, decorator, stylist, costume designer, visual artist, florist, builder, set designer, ceramist, chef, interior designer, jewelry designer, graphic designer; entrepreneurial activities related to management capacity - businessman, executive, administrator, financial market professional; with social, communication and cooperation relationships - luxury market consultant, realtor, lawyer, economist, marketing professional, art director, doctor, nutritionist, occupational therapist.

Residents wanted to set up showrooms, create office, get multipurpose spaces, integrate private and work areas, occupy, transform, unite and eliminate pre-existing rooms, optimize the spaces of the house/home; adapt the furniture. The work invaded the corridor, the bedroom, the bathroom, the $1 \mathrm{~m}^{2}$ corner, with the removal of walls, the creation / displacement of openings, the replacement of walls by frames - sliding panels, camouflaged, hollow, glass openings - and by flexible and light furniture. Clearly, you can see versatile-reversible-customizable walls (FONSECA JORGE, 2013), and post-wall architecture (ELEB, 2011; MENDONÇA, 2010; TRAMONTANO and REQUENA, 2007). But also you can see work markers distributed in house/home in a gradient perspective - isolated, compartmentalized, semi-integrated, integrated spaces, corners, doublesided bookshelves, countertops, multipurpose sideboards, sofa, bed. 
Thus, there is the displacement of a coding for an operation (DELEUZE and GUATTARI, 2004; HUR, 2015; GORZ, 2005; LAZZARATO and NEGRI, 2001). In the logic of immaterial labor and, at a distance, capital controls the worker who has "[...] many ways to save his honor and 'his soul' (GORZ, 2005, p. 23)", including by making it well-known that, at home, he works in the living room meeting with colleagues, down the hall welcoming clients, in the bedroom setting up meetings, answering emails, posting on the internet.

In the hybrid space of the house/home, relatives, friends, customers, co-workers circulate, connected by messages, chats, videoconferences, social networks. Immaterial labor therefore promotes confinement beyond factory/business boundaries, even if individuals perceive themselves as free. However, from the perspective presented by the magazine, working at house/ home is reduced only to the idea of meeting personal goals: to stop working confined; maintaining coexistence and stay close to the children; working at home as a priority and with more pleasure; spread on a turkish bed; with freedom; focused; with everything going on around; concomitantly with other tasks; in the evening. Modest, thus, they seem not to coincide with the demands of immaterial labor, nor with the axiomatic of capitalism. Taken to the reinterpretation (THOMPSON, 2005), in front of the presented axes, they constitute elements of another axiom incorporated to the flow of the axiomatic of capitalism - the dwelling-working.

\section{CONCLUSION}

When capital and immaterial labor, free from spatiotemporal patterns, show noticeable mobility, they allude to the equivalent mobility / freedom of the worker. The acquisitions of the present study allow us to consider, however, that while capital expands and let loose, mobility has a different repercussion for the imprisoned worker who finds himself in a supposed freedom.

The analysis axes presented - (com)position of the theme in the magazine and (re)functionalization, monetization and naturalization of the house / home for working - enable considering the analyzed media as one of the elements that serve the action / maintenance / propagation of the axiomatic of capitalism in the house/home, taking into account dwelling-working as another axiom (DELEUZE and GUATTARI, 2004; HUR, 2015).

In Casa Claudia, new ways of life and organization of production in contemporary capitalism are axiomatized based on new trends in the segments of architecture, decoration and home design. It was shown how the weakening of the division between work and house/home and how the axiomatization of this productive transformation not only goes through the architectural trends suggested by the magazine, but also that these trends were initially announced as a novelty on the covers of the issues in order to, little by little, be shown in the articles already as something definitively assimilated - axiomatized.

Through the media of the architecture, decoration and design segments, the axiomatic of capitalism acts in an unsuspecting and non-confrontational way, reinforcing the "[...] way of life established by capitalism" (DOREA, 2002, p. 102). In a stimulated, widespread and disguised capture, the axiomatic of capitalism interferes with the house / home in order to affect / alter its traditional features of refuge and place of energy replacement for work (CORREA, 2004), for the place of work and possibility of extension and shelter of the capital. Coupled with new technologies and new means of worker control, the axiomatic of capitalism operates globally and locally, in material and immaterial, dominating the most minimally located space (SANTOS, 2002), including the smallest and most unusual corners of intimate life - little space between sliding closet door and bedside table in a double bedroom. Eliminating papers from the desk, picking up the purse, turning off the lights and leaving the office, going through the living room door and feeling at home, even though they may be taken as resisting actions, prove innocuous to the axiomatic of capitalism.

Given the relevance of the results achieved on how life is animated in the house/home due to the axiomatic of capitalism, it is recommended that future studies also focus on other media, expanding the temporal and local cut, and considering gender, generation and social class specificities. 
Living-working and the axiomatic of capitalism: a study based on media outlets in the architecture, decoration, and design segments
Ana Carolina dos Santos Bortolini

Carmem Ligia Iochins Grisci Ana Elísia da Costa

\section{REFERENCES}

AMORIN, L.; GRIZ, C.; LOUREIRO, C. É permitido permitir: das alterações do produto imobiliário e dos modos de morar contemporâneo no Recife. V!rus, São Carlos, n. 5, 2011. Available at: <http://www. nomads.usp.br/virus/virus05/?sec=4\&item=1\&lang=pt>. Accessed on: Apr. 04, 2018

BAUER, M.W.; AARTS, B. A construção do corpus: um princípio para a coleta de dados qualitativos. In: BAUER, M.W.; GASKELL, G. Pesquisa qualitativa com texto, imagem e som: um manual prático. Petrópolis: Vozes, p. 39-63, 2002.

BAUMAN, Z. Vida para consumo: a transformação das pessoas em mercadoria. Rio de Janeiro: Zahar, 2008.

BAUMAN, Z.; MAY, T. Aprendendo a pensar com a sociologia. Rio de Janeiro: Zahar, 2010.

CASA CLÁUDIA. [Site]. Available at: <https://casaclaudia.abril.com. br>. Accessed on: Mar. 12, 2018.

CORREA, T. B. A construção do habitat moderno no Brasil: 18701950. São Carlos: Rima, 2004.

DAL ROSSO, S. Mais trabalho! A intensificação do labor na sociedade contemporânea. São Paulo: Boitempo, 2012.

DELEUZE, G. Proust e os signos. Rio de Janeiro: Forense Universitária, 1987.

DELEUZE, G. Derrames: entre o capitalismo y la esquizofrenia. Buenos Aires: Cactus, 2005.

DELEUZE, G.; GUATTARI, F. O Anti-Édipo: capitalismo e esquizofrenia. Lisboa: Assírio \& Alvim, 2004.

DELEUZE, G.; GUATTARI, F. Mil Platôs: capitalismo e esquizofrenia. v. 3. Rio de Janeiro. Ed. 34, 1996.

DELEUZE, G.; GUATTARI, F. Mil Platôs: capitalismo e esquizofrenia. v. 5. Rio de Janeiro. Ed. 34, 1997.

DOREA, G. Gilles Deleuze e Feliz Guattari: heterogênese e devir. Margem, São Paulo, n.16, p. 91-106, 2002.

ELEB, M. Lugares, gestos e palavras do conforto em casa. V!rus, São Carlos, v. 5, 2011. Available at: <http://www.nomads.usp.br/virus/ virus05/?sec=3\&item=1\&lang=pt>. Accessed on: Apr. 04, 2018.

FARIAS, A. Editorial. Casa Cláudia, São Paulo, Aug.2006.

FERREIRA, A. Menos é mais. Casa Cláudia, São Paulo, Nov. 2015.

FONSECA JORGE, P. A. A dinâmica do espaço na habitação mínima. Arquitextos, São Paulo, ano 14, n. 157.01, June 2013. Available at: <http:// www.vitruvius.com.br/revistas/read/arquitextos/14.157/4804>. Accessed on: Apr. 06, 2018.

GORZ, A. O imaterial: conhecimento, valor e capital. São Paulo: Annablume, 2005.

GUÉRON, R. A axiomática capitalista segundo Deleuze e Guattari. De Marx a Nietzsche, de Nietzsche a Marx. Revista de Filosofia: Aurora, Curitiba, v. 29, n. 46, p. 257-282, Jan./Apr. 2017.

HARDT, M. A sociedade mundial de controle. In: ALLIEZ, É. (Org.). Gilles Deleuze: uma vida filosófica. São Paulo: Ed. 34, 2000. p. 357-372.

HARDT, M.; NEGRI, A. Multidão: guerra e democracia na era do império. Rio de Janeiro: Record, 2005.

HUR, D. Axiomática do capital e instituições: abstratas, concretas e imateriais. Revista Polis e Psique, v. 5, n. 3, p. 156-178, 2015.

ITUASSU, C. T.; TONELLI, M. J. Sucesso, mídia de negócios e a cultura do management no Brasil. Cadernos EBAPE.BR, Rio de Janeiro, v. 12, n. 1, p. 86-86, 2014.

LAZZARATO, M; NEGRI, A. Trabalho imaterial: formas de vida e produção de subjetividade. Rio de Janeiro: DP\&A Editora, 2001.

MENDONÇA, M. A inclusão dos "home offices" no setor residencial no município de São Paulo. 2010. Thesis (Doctor Degree in Architecture Technology) - Faculdade de Arquitetura e Urbanismo, Universidade de São Paulo, São Paulo, 2010.

MINAYO, M. C. S. (Org.). Pesquisa social: teoria, método e criatividade. Petrópolis: Vozes, 2003.

PELBART, P. P. A vertigem por um fio: políticas da subjetividade contemporânea. São Paulo: Iluminuras, 2000.

RODRIGUES, A.; MORIN, E.; STREHLAU, S. A imagem de executivos na mídia: um estudo com jornais de Québec. Cadernos EBAPE.BR, Rio de Janeiro, v. 7, n. 2, p. 232-251, 2009.

SANTANA, C. Editorial. Casa Cláudia, São Paulo, Aug. 2007.

SANTOS, L. Código primitivo - código genético: a consistência de uma vizinhança. In: ALLIEZ, É. (Org.). Gilles Deleuze: uma vida filosófica. São Paulo: Ed. 34, 2000. p. 397-414.

THOMPSON, J. B. Ideologia e cultura moderna: teoria social crítica na era dos meios de comunicação de massa. Petrópolis: Vozes, 2005.

TRAMONTANO, M.; REQUENA, G. Living ways: design processes of a hybrid spatiality. International Journal of Architectural Computing, v. 5, n. 3, p. 535-549, 2007. 


\section{Carmem Ligia lochins Grisci}

ORCID: https://orcid.org/0000-0002-7034-4007

PhD in Psychology; Full Professor at the School of Administration of the Federal University of Rio Grande do Sul (EA / UFRGS), Porto Alegre - RS, Brazil

E-mail: carmem.grisci@ufrgs.br

\section{Ana Elísia da Costa}

ORCID: https://orcid.org/0000-0003-4829-5699

PhD in Architecture; Professor at the School of Architecture and Urbanism of the Federal University of Rio Grande do Sul, Porto Alegre - RS, Brazil. E-mail: ana_elisia_costa@hotmail.com 